\title{
URGENSI KEBIJAKAN PIDANA DALAM PEMBERANTASAN KORUPSI DI INDONESIA
}

\author{
Oleh :
}

\section{Ketut Maha Agung}

\begin{abstract}
Corruption in Indonesia has been so severed and widespread in the community and very alarming, its development continues to increase from year to year, both in number of cases and the amount of state financial osses and in terms of qauality. These criminal of fences commit more systematic and scope into all aspects of life. Starting from lower level of the dominant and state officials or law inforcer. The constraints in the implementation of the court decision related to the return of states losses is convicted assets and property that has been transfered. It's ower problem in the law enforcement of corruption.

It's to ned of step ciminal polity to fight againts corrupiton to use of method is a system and must to do is integrated from law inforcer and public society.
\end{abstract}

Key words : Criminal Policy, To Fight Againts, Corruption

\section{PENDAHULUAN}

Bagi Indonesia pengaturan korupsi berupa pidana maupun peinidanaan bukan merupakan persoalan baru. Pemerintah bersama badan legislatif telah banyak mengambil langkah kebijakan di bidang korupsi ini.

Penanganan korupsi berupa kebijakan dan pengaturannya sudah dimulai tindakan itu secara formal oleh pemerintah atas pelopor kalangan militer sejak tahun 1960 dengan Undang-Undang No : 24 Prp 1960, yang secara berturut-turut berikutnya silih berganti diberlakukannya undang-undang di bidang Pemberantasan Pidana Korupsi seperti Undang-Undang No : 3 Tahun 1971, Undang-Undang No : 31 Tahun 1999 dan Undang-Undang No : 20 Tahun 2001 (Tentang Perubahan atas Undang-Undang No : 31 Tahun 1999 tentang Pemberantasan Tindak Pidana Korupsi). Dan terakhir dibentuknya Komisi Pemberantasan Korupsi dengan Undang-Undang No : 30 tahun 2002.

Dari rangkaian pemberlakuan beberapa undang-undang dalam penanganan dan pemberantasan korupsi di Indonesia, belum pernah mencapai hasil yang diharapkan, bahkan bahaya korupsi semakin dirasakan menyengsarakan rakyat. Hal ini terbukti salah satu penyebab tiinbulnya krisis multidimensi di Indonesia adalah dari korupsi ini, dan atas perintah ketetapan (TAP) MPR Nomor : IV/ MPR/1999 antara lam agar ditegakkannya supremasi hukum dan pemberantasan Korupsi, Kolusi dan Nepotisme (KKN). ${ }^{1}$

Pemberantasan korupsi memang bukan beban bagi Indonesia saja, hal ini diakui oleh Robert Klitgaard (dalam buku karyanya Controlling Corruption 1991) bahwa

\footnotetext{
Leden Marpaung, Tindak Pidana Korupsi Pemberantasan dan Pencegahan, Penerbit Djambatan, Jakarta, 2001, hlm.11.
} 
Corruption is one of the foremost problem in the developing word and it is receiving much greather attention as we reach the las decade of the century" (Korupsi merupakan salah satu masalah paling besar dinegara berkembang, dan masalah itu semakin menarik perhatian begitu kita ipemasuki dekade terakhir abad 20). ${ }^{2}$

Kesulitan pemberantasan korupsi menurut pembaharu besar Cina bernama Wang An Sihih (1021-1086) bersumber pada buruknya hukum dan buruknya manusia. ${ }^{3}$

Senada dengan pernyataan di atas, bahwa dalam penanganan korupsi Lon L. Fuller menyatakan "I have insisted that law be viewed as a purposeful enterprise, dependent for its success on the energi, insight, intellegence and consciousness of those who conduct it" (secara tegas saya melihat hukum sebagai suatu upaya dengan maksud tertentu, keberhasilannya tergantung pada energi, wawasan, inteligensia, dan kesadaran dari para pelaku hukum. ${ }^{4}$

Untuk penanganan korupsi di Indonesia kegagalan selama ini akibat berbagai fakior yang terakomulasi, sehingga pemberantasan koaipsi menjadi semakin rumit, walaupun dari segi aturan pidana dan pemidanaannya selalu sudah diadakan revisi.

Silih bergantinya peraturan atau undang-undang yang diciptakan sebagai langkah kebijakan memperbaharui aturan sebelumnya, belum menjamin keberhasilan dalam pemberantasan tindak pidana korupsi

Robert Klitgaard (Dalam Achmad Ali). Keterpurukan Hukum di Indonesia (Penyebab dan Solusinya), Ghalia Indonesia, Jakarta, 2001, hlm.15.

3 Syeh Hussein Alatan, Sosiolog Korupsi, Sebuah Penjelajahan Dengan Data Komtemporer, Terbitan LP3ES, 1983, hlm.7.

$4 \quad$ Achmad Ali, Op Cit, hlm.7. yang muncul. Pencantuman sanksi (pidana) dan pemidanaan yang berat tidak menjamin pelaku korupsi akan berkurang.

Karena dipandang semakin rumitnya penanganan korupsi di Indonesia, sampai timbul gagasan dari Abdul Hakim Garuda Nusantara untuk membentuk pengadilan khusus korupsi sebagai solusi alternatif penyelesaian kasus korupsi misalnya membentuk Pengadilan Ad Hoc Korupsi di Indonesia. $^{5}$

Pada saat ini "penyidikan" tindak pidana korupsi dilakukan baik oleh kejaksaan maupun oleh penyidik Polri.

Dalam perkembangan paling akhir dengan dibentuknya Komisi Pemberantasan Tindak Pidana Korupsi oleh pemerintah dan telah mendapat persetujuan dan pengesahan dari DPRD RI dari RUU menjadi undangundang (tanggal 28 Nopember 2002), maka bertambah lagi lembagayang mempunyai kewenangan dalam menyidik Tindak Pidana Korupsi (Terciptanya UU No : 30tahun 2002 tentang Komisi Pemberantasan Tindak Pidana Korupsi).

Karena Komisi Pemberantasan Tindak Pidana Korupsi yang terbentuk ini sesuai penunusan pasal 43 ayat (2) Undang-Undnag No : 31 Tahun 1999 memberikan tugas dan wewenang melakukan koordinasi dan supervisi tennasuk melakukan penyelidikan, penyidikan dan penuntutan dalam Tindak Pidana Korupsi, maka kewenangannya sangat luas.

Terhadap pengaturan pemberian tugas dan kewenangan sebagai penyidik dalam tindak pidana korupsi masih terjadi

Abdul Hakim Garuda Nusantara, Tajuk Dalam Komisi Hukum Nasional (KHN) RI, Edisi Mei, 2002, hlm.7. 
conflict of norm (pengaturan norma yang telah terwujud dalam kaedah) hukum positif yang saling memberikan peluang tugas dan kewenangan seperti polisi (penyidik Polri), Kejaksaan, serta Komisi Pemberantasan Tindak Pidana Korupsi, selaku aparat “penyidik" dalam tindak pidana korupsi.

Tindak pidana korupsi digolongkan ke dalam tindak pidana khusus, karena disamping secara hukum pidana materiil pengaturan korupsi tidak ada diatur secara spesifik dalam KUHP, juga secara hukum formilnya secara khusus sebagai ciri atau karakteristik tindak pidana di luar KUHP ini dalam KUHAP juga tidak lengkap mengaturnya, sehingga korupsi dimasukkan sebagai klasifikasi tindak pidana di luar KUHP atau dengan sebutan Tindak Pidana Khusus. Dan sebutan khusus ini Tindak Pidana Korupsi menurut Undang-Undang No : 31 Tahun 1999 memuat ketentuanketentuan khusus pula.

Dengan adanya kekhususankekhususan dari Tindak Pidana Korupsi tersebut, perlu pula akan adanya terobosanterobosan kebijakan dalam menanggulangi dan mencegah korupsi ini dan pemerintah bersama legislatif, baik berupa tindakan penyimpangan dari aturan umum maupun penciptaan aturan yang sifatnya khusus dan istimewa bila dipandang diperlukan untuk inemberantas korupsi tersebut, terutama menyangkut pidana dan pemidanaannya.

Paparan latar belakang masalah yang terurai diatas, maka penulis rumuskan permasalahan seperti berikut :

1. Bagaimana pengaturan pidana dan pemidanaan tindak pidana korupsi dalam hukum positif Indonesia?

2. Apa bentuk kebijakan pidana (criminal policy) dalam pemberantasan korupsi di Indonesia?

\section{METODELOGI}

\subsection{Jenis Penelitian}

Penelitian karya ilmiah ini tergolong ke dalam jenis penelitian hukum normatif atau penelitian hukum kepustakaan, karena penelitian hukum ini dilakukan dengan cara meneliti bahan kepustakaan (library research) yang terdiri dari bahan hukum primer dan ditunjang oleh bahan hukum sekunder

Menurut Soerjono Soekanto dan Sri Mamudji, penelitian hukum normatif atau kepustakaan tersebut mencakup:

1. Penelitian terhadap asas-asas hukum

2. Penelitian terhadap sistematik hukum

3. Penelitian terhadap taraf sinkronisasi vertikal dan horisontal

4. Perbandingan hukum

5. Sejarah hukum ${ }^{6}$

Sehubungan denganklasifikasitersebut diatas, maka penelitian hukum normatif ini menyangkut penelitian taraf sinkronisasi horisontal atas disharmonisasi norma yang ada antara UU No. 31 Tahun 1999 jo UU No. 20 Tahun 2001 tentang Pemberantasan Tindak Pidana Korupsi dengan UU terkait dalam penanganan pemberantasan tindak pidana korupsi di Indonesia sebagai langkah kebijakan kedepan.

\subsection{Metode Pendekatan}

Sesuai dengan karakteristik dan sifat penelitian normatif, maka dalam penelitian

Soerjono Soekanto dan Sri Mamudji, 2001, Penelitian Hukum Normatif^ PT. Raja Grafindo Persada, Jakarta, hlm.14. 
ini akan memakai beberapa metode pendekatan diantaranya :

- The Statue Approach pendekatan perundang-undangan

- The Analitical and Conseptual Approach (pendekatan analisis konsep hukum)

\subsection{Sumber Bahan Hukum}

Penelitian hukum bersifat normatif, maka jenis bahan hukum yang lazim dipergunakan adalah :

a. Bahan- bahan hukum primer

b. Bahan - bahan hukum sekunder

c. Bahan - bahan hukum tersier ${ }^{7}$

Sehubungan dengan penelitian hukum normatif ini, maka memakai sumber bahan hukum dari :

1. Bahan hukum primer, seperti :

Undang-Undang No. 8 Tahun 1981 tentangKUHAP

- $\quad$ Undang-Undang No. 31 Tahun 1999 jo Undang - Undang No. 20 Tahun 2001 tentang Pemberantasan Tindak Pidana Korupsi

- Undang - Undang No. 30 Tahun 2002 tentang Komisi Pemberantasan Korupsi (KPK)

2. Bahan hukum sekunder, yakni memberikan penjelasan mengenai bahan hukum primer

3. Bahan hukum tersier, dalam hubungan penelitian ini menyangakut seperti kamus ensiklopedi.

\subsection{Metode Pengumpulan Bahan \\ Hukum}

Penelitian ini untuk pengumplan bahan hukum memakai metode sistematis,

Ronny Hamijoyo Soemantri, 1998, Metode Penelitian Hukum dan Jurimetri, Ghalia Indonesia, Jakarta, hlm.11-12. yakni berupa pengumpulan bahan peraturan perundang-undangan

\subsection{Teknik Analisis Bahan Hukum}

Menggunakan teknis analitis seperti:

- $\quad$ Teknik diskripsi

- $\quad$ Teknik interpretasi

- $\quad$ Teknik evaluasi

- $\quad$ Teknik argumentasi

- Teknik sistematisasi

- $\quad$ Metode konstruksi hukum

\section{HASIL PENELITIAN / PEMBAHASAN}

Penelitian kepustakaan ini menghasilkan kajian dari problem teoritik, sebagai wawasan keilmuan hukum.

\subsection{Pengertian dan makna daribeberapa istilah}

\subsection{Kebijakan}

Sebagai suatu konsekuensi logis dan yuridis bagi negara Indonesia yang menyatakan diri sebagai negara hukum sesuai penunusan pasal 1 angka (3) UUD 1945, dengan corak pemerintahan demokrasi (Pancasila), dan dengan tipe negara kesejahteraan (welfare states), maka untuk kesejahteraan atau kemakinuran warga negaranya, negara dengan berbagai cara yang ditempuhnya berusaha menempuh berbagai kebijakan yang dipandang perlu.

Untuk penyelenggaraan kebijakan oleh negara dikenal dengan istilah menempuh kebijakan publik (public policy).

Pengertian kebijakan (kebijaksanaan) seperti dikemukakan oleh James E. Anderson, bahwa kebijaksanaan itii adalah: "A purposive course of action followed by an actor or set of actor in dealing with a problem or matter of carcern" ("serangkaian tindakan mempunyai tujuan iertentu yang 
diikuti dan dilaksanakan oleh seorang pelaku atau sekelompok pelaku guna memecahkan suatu masalah tertentif. Sedangkan Thomas R. Dye mendefinisikan kebijaksanaan negara sebagai, "is whatever governements chose to do or not to do," (apapun yang dipilih oleh pemerintah untuk dilakukan atau tidak dilakukan $^{8}$

Dari kedua defmisi di atas tentang apa itu kebijakan (public policy), menampakkan bahwa negara baik aktif maupun pasif, sebagai pemegang peran kebijakan publik, guna memecahkan masalah tertentu.

- Tindak pidana, istilah "Tindak pidana adalah dimaksudkan sebagai terjemahan dalam bahasa Indonesia untuk istilah Bahasa Belanda" Strafbaarfeit" atau "Delict".

Untuk terjemahan itu, dalam bahasa Indonesia, disamping istilah tindak pidana, juga telali dipakai dan beredar beberapa istilah lain baik dalam bukubuku ataupun dalam peraturan tertulis yang penulis jumpai antara lain : "Perbuatan yang dapat dihukum" (1), "Perbuatanyang boleh dihukum" (2), "Peristiwa Pidana" (3), "Pelanggaran pidana" (4) dan "Perbuatan pidana (5). ${ }^{9}$

Menurut Muljamo, beliau memakai istilah perbuatan pidana, yang merumuskan : "perbuatan yang oleh aturan hukum pidana dilarang dan diancam dengan pidana barang siapa yang melanggar larangan tersebut. Dari

Irfan Islamy, Kebijakan Publik, Cetakan 1, Karunika Jakarta, 1984, hlm.17-18.

9 K. Wantjik Saleh, Tindak Pidana Korupsi dan Suap. Cet. Ke 5, Ghalia Indonesia, Jakarta 1983, hlm.15. apa yang disebutkan di atas kiranya dapat ditarik kesiinpulan bahwa suatu perbuatan akan menjadi suatu tindak pidana apabila perbuatan itu :

a. Melawan hukum.

b. Merugikan masyarakat.

c. Dilarang oleh aturan pidana.

d. Pelakunya diancam dengan pidana ${ }^{10}$

Korupsi, secara etimologi, korupsi berasal dan perkataan bahasa latin "corruptio" yang berarti kenisakan, atau kebobrokan yang dipakai untuk menunjuk keadaan atau perbuatan yang busuk ${ }^{11}$

Sedangkan menurut World Dectionary of the American Language, sejak abad pertengahan Inggns dan Perancis menggunakan kata Corruption yang mengandung arti :

- Perbuatan atau kenyataan yang menimbulkan keadaan yang bersifat buruk.

- Perilaku yang jahat dan tercela atau kebejatan moral.

- Penyuapan dan bentuk-bentuk ketidakjujuran.

- Kebusukan atau tengik.

- Sesuatu yang dikorup, seperti kata yang dirubah atau diganti secara tidak tepat dalam suatu kalimat.

- Pengaruh-pengaruh yang korup. ${ }^{12}$

Dalam Kamus Besar Bahasa Indonesia, dimuat pengertian korupsi

Ibid.hlm.16.

11 Soedjono Dirdjosisworo, Fungsi PerundangUndangan Pidana Dalam Penanggulangan Korupsi di Indonesia Penerbit Sinar Baru Bandung, 1984, hlm.16.

12 William Collin, (dalam Soedjono D), Op. Cit. hlm.172. 
sebagai berikut: "Penyelewengan atau penggelapan (uang negara atau perusahaan, dan sebagainya untak keuntungan pribadi atau orang lain). ${ }^{13}$

Dalam Undang-Undang No : 28 Tahun 1999 tentang Penyelenggaraan negara yang bersih danbebas dari korup, kolusi dan nepotisme, padaPasal 1 butir 3 dimuat pengertian korupsisebagai berikut:"Korupsi adalah tindak pidana sebagaimana dimaksud dalam ketentuan peraturan perundangundangan yang mengatur tentang tindak pidana korupsi."

- Pengertian korupsi dari beberapa pendapat para ilmuan memberikan defmisi atau ciri-cirikorupsi seperti diantaranya:

- Menurut Bayley, korupsi dikaitkan dengan perbuatan penyuapan yang berhubungan dengan penyalahgunaan wewenang atau kekuasaan sebagai akibat adanya pertimbangan dari mereka yang memegangjabatan bagikeuntungan pribadi.

- Menurut J.S. Nye, korupsi sebagai prilaku yang menyimpang dari kewajiban-kewajiban normal suatu perananjawatan pemerintah, karena kepentingan pribadi (keluarga, golongan, kawan akrab), demi mengejar status dan gengsi, atau melanggar peraturan dengan jalan melakukan atau mencari pengaruh bagi kepentingan pribadi.
Departemen Pendidikan dan Kebudayaan Republik Indonesia, Kamus Besar Bahasa Indonesia, BP., Jakarta, 1976, hlm.527.
- Menurut M.MC. Mullan, seseorang pejabat pemerintah dikatakan korup, apabila ia menerima uang yang dirasakan sebagai dorongan untuk melakukan sesuatu yang ia bisa lakukan dalam tugas jabatannya, padahal ia selama menjalankan tugasnya seharusnya ridak boieh berbuat demikian.

- Jacob Van Klaveren, yang mengemukakan bahwa seorang pengabdi negara (Pegawai Negeri) yang berjiwa korup menganggap kantor jawatannya sebagai suatu perusahaan dagang dimana pendapatannya akan diusahakan semaksimal mungkin.

- Carl J. Friedrich, bahwa pola korupsi dapat dikatakan ada apabila seorang pemegang kekuasaan yang berwenang untuk melakukan hal tertentu seperti pejabat yang bertanggung jawab melalui uang atau semacam hadiah lainnya yang tidak diperbolehkan oleh undang-undang (secara tidak sah) membujuk untuk mengambil langkah yang menolong siapa saja yang menyediakan hadiah dan dengan demikian benar-benar membahayakan kepentingan umum. $^{14}$

- Menurut Hussein Alatas, korupsi dalam prakteknya menunjukkan ciri-ciri sebagai berikut:

a. Korupsi senantiasa melibatkan lebih dari satu orang. 
b. Korupsi pada umumnya dilakukan secara rahasia.

c. Korupsi melibatkan elemen kewajiban dan keuntungan timbal balik.

d. Mereka yang melakukan korupsi dengan berbagai cara biasanya berlindung dibalikpembenaran hiikum.

e. Mereka yang terlibat korupsi adalah yang menginginkan keputusau yang tegas danmereka yang mempengaruhi keputusan itu.

f. Tindakan korupsi mengandung penipuan baik pada badan publik atau masyarakat umum

g. Setiap bentuk korupsi adalah suatu pengkhianatan kepercayaan

h. Setiap bentuk korupsi melibatkan fungsi ganda yang kotradiktif dan mereka yang melakukan itu. ${ }^{15}$

\subsection{Pengaturan Pidana dan Pemidanaan} Tindak Pidana Korupsi Dapat Ditinjau Dari Rangkaian Kronologis

Historis Pembaharuan Peraturan Perundang-Undangan Korupsi Sebagai Kebijakan Pidana (Criminal Policy) Dalam Pembaharuan Hukum Pidana Sebagai Berikut :

Terhadap permasalahan diatas akan dikaji melalui penelusuran perkembangan sejarah perundang-undangan korupsi di Indonesia dalam kurun waktu periodesasi (1957-2002) sejak mulai tampak adanya usaha penanggulangan dan pemberantasan korupsi di Indonesia, sebagai langkah

15 Syeh Hussein Alatan, Op Cit., hlm. kebijakanpemerintahbersamabadanlegislatif di bidang hukum pidana khususnya

\subsection{Periode I : Gagasan Penanganan} Korupsitimbul dari kalangan Militer atas dasar Peraturan "'Penguasa Militer No : Prt/PM.06/1957.

Lahirnya peraturan militer iiii dipandang sebagai peletak dasar peraturan penanganan kompsi di Indonesia, karena KUHP tidak mampu mengatasi perbuatan yang berindikasi mengarah unsur-unsur konipsi, seperti diatur dalam Bab XXVIII, yang dikelompokkan dalam perbuatan : I. Penggelapan (pasal 415), 2. Pemalsuan (pasal 416), 3. Menerima suap (pasal 418-420), 4. Perbuatan menguntungkan din sendiri secara tidak sah (pasal 423, 425 dan 435) KUHP. Pada saat ini tarap kerugian yang muncul sebagai akibat perbuatan mengandung unsur indikasi korupsi baru hanya perorangan, serta ancaman pidana dalam KUHP maksimal 4-6 tahun penjara.

Tindak lanjut peraturan penguasa militer No : PRT/PM.06/1957, disusul dengan dikeluarkannya peraturan seperti :

a. Peraturan Penguasa Militer No : Prt/PM.08/1957 tanggal 27 Maret 1957 tentang pemilikan harta benda, dalam pemilikan harta benda ini, dimungkinkan adanya penyitaan terhadap :

1. Harta benda atau barang yang dengan sengaja atau karena kelalaian tidak diterangkan oleh pemiliknya atau pengurusnya.

2. Harta benda yang tidak terang siapa pemiliknya.

3. Harta benda orang yang kekayaannya oleh pemilik atau 
pemilik pembantu harta benda dianggap diperoleh secara mendadak dan mencurigakan.

b. Peraturan Penguasa Militer No : Prt/ PM.Ol 1/1957 tanggal 1 Mi 1957, tentang kewenangan Penguasa Militer menyita harta benda (tersebut di atas), juga dimuat batasan pengertian kata perbuatan melawan hukum (onrechtmatigedaad) dalam artian luas, bukan saja melawan hukum dengan aturan hukum tertulis, juga perbuatan melawan hukum yang bertentangan dengan rasa kepatutan, kesopanan dan sebagainya.

Ketika undang-undang keadaan bahaya Undang-Undang No : 74 tahun 1957 diberlakukan, makaketiga Peraturan Penguasa Militer tersebut di atas diganti, dan atas kewenangan Penguasa perangdibuat dan diundangkan aturan baru :

1. Peraturan Penguasa Perang Pusat Angkatan Darat No : Prt/ Peperpu/013/1958 tertanggal 16 April 1958 tentang Pengusutan, Penuntutan dan Pemeriksaan Perbuatan Korupsi Pidana dan Pemilikan harta benda (berlaku pada daerah-daerah yang dikuasai Angkatan Darat).

2. Dan untuk daerah-daerah yang dikuasai oleh Angkatan Laut, diatur $\wedge$ dengan Peraturan Penguasa Perang Pusat KASAL No : Prt/Z.I/I/7 tangggal 17 April 1958, yang dengan aturan ini pula bertujuan untuk memberantas perbuatan-perbuatan korupsi yang saat itu sangat merajalela, pemerintah seakan-akan sudah tak berdaya untuk mengatasinya.
Perumusan tentang perbuatan korupsi pidana pada peraturan di atas meliputi:

a. Perbuatan Korupsi Pidana

1. Perbuatan seseorang yang dengan atau karena melakukan suatu kejahatan atau pelanggaran memperkaya diri sendiri atau orang lain atau sesuatu badan yang secara langsung atau tidak langsung merugikan keuangan atau perekonomian negara atau daerah atau merugikan suatu badan keuangan negara atau daerah dan badan hukum lain, yang mempergunakan modal atau kelonggaran-kelonggaran dari masyarakat.

2. Perbuatan yang dengan atau karena melakukan sesuatu kejahatan atau pelanggaran memperkaya diri sendiri atau orang lain atau suatu badan. serta yang dilakukan dengan menyalahgunakan jabatan atau kedudukan.

b. Perbuatan korupsi lainnya

1. Perbuatan seseorang yang dengan atau karena melakukan perbuatan melawan hukum memperkaya diri sendiri atau orang lain atau suatu badan yang secara langsung atau tidak langsung merugikan keuangan negara atau daerah atau merugikan keuangan suatu badan yang meneriina bantuan dari keuangan negara atau daerah atau badan lain yang mempergunakan modal dan kelonggaran-kelonggaran dari masyarakat.

2. Perbuatan seseorang yang dengan atau karena melakukan perbuatan melawan hukum memperkaya diri sendiri atau orang lain atau suatu badan dan yang 
dilakukan dengan menyalahgunakan jabatan. ${ }^{16}$

Dengan adanya kreteria pembedaan antara perbuatan korupsi pidana dan perbuatan korupsilainnya, maka amat sulit untuk menindak pelakunya, karena harus mencari pembedaan yang jelas antara mana perbuatan korupsi pidana dan mana perbuatan korupsi lainnya, dalam proses pembuktiannya akan sulit, sehingga pelaku mudah lolos dari jeratan hukum. Karena ukuran perbuatan korupsi lainnya beipegang pada rasa kevvajaran dan syarat perbuatan tercela. Hal itulah merupakan kendala besar dalam proses pembuktian dan penanganan kasus korupsi dimana berlakunya peraturan yang dikeluarkan pihak penguasa militer.

Dalam peraturan penguasa militer ini mulai tampak istilah penyebutan "perbuatan korupsi”.

\subsection{Periode II : Berupa Penggantian Peraturan Penguasa Militer Menjadi Peraturan Pemerintah Pengganti Undang-Undang/Lahirnya Undang- Undang No : 24 Prp. Tahun 1960.}

Pembaruan Peraturan Penguasa Perang Pusattersebutdilakukanmelaluipengunmgan Peraturan Pemenntah Pengganti UndangUndang Nomor : 24 tahun 1960 tanggal 9 $\mathrm{Jb}$ tentang Pengusutan Penuntutan dan Pemeriksaan Tindak Pidana Korupsi, yang kemudinn menurut Undang-Undang Nomor : 1 tahun 1961 sejak tangggal 1 Januari 1961 telah $\mathrm{m}$ imdang-undang dan disebut dengan Undang-Undang No : 24 Prp tahun 1960, karena saat ini undang-undang ini dibentuk

16 Soedjono Dirdjosisworo, Op Cit., hlm.57. keadaan dalam kondisi memaksa dan situasi darurat maka bentuk awalnya berupa Peraturan Pemenntah Pengganti UndangUndang atau sering disebut Undang Anti Korupsi. Adapun rumusan Tindak Pidana Korupsi dalam Undang-Undang alum 1960 adalah :

1. Sama dengan batasan Perbuatan Korupsi Pidana.

2. Sama dengan batasan Perbuatan Korupsi Lainnya (halaman di depan).

3. Kejahatan-kejahatan tercantum dalam pasal 17 sampai pasal 21 peraturan im penyuapan aktif kepada pejabat), seperti tertuang dalam pasal-pasal 209. 210. 4V 420, 423, 425 dan pasal 435 KUHAP. ${ }^{17}$

Perkembangan kearah kemajuaii dan Undang-Undang No : 24 tahun 1960 mi nampak, karena kesuhtan pembtiktian terhadap pelaku korupsi masih sulit terungka, masih tetap ada pembedaan Perbuatan Korupsi Pidana dan Perbuatan Korupsi Lamny mempertegas kembali unsur perbuatan yang digolongkan tmdakan suap kepada pemenntah (seperti diatur dalam pasal-pasal KUHP tersebut di atas), yang digolongkan tinakan korupsi. Dalam hal ini terjadi usaha untuk menarik pasai-pasal KUHP yang be indikasi korupsi menjadi bentuk tindak pidana korupsi. Dampak negatif yang muncul bu kondisi keuangan pemenntah yang berpengaruh pada kehidupan politik, ekonomi, sosial keamanan rakyat. Penjatuhan sanksi pidana tidak tegas, banyak koruptor lolos dan hukum.

17 Soedjono Dirdjosisworo, Op Cit. hlm.58. 
3.6. Periode III : Lahirnya UndangUndang No : 3 tahun 197K tentang Pemberantasan Ilndak Pidana Korupsi (LN.1971 No : 19), yang diundangkan pada tanggal 29 Maret 1971 (selbagai pengganti UndangUndang No : 24 Prp. 1960).

Menurut ketentuan pasal 1 UndangUndang No ; 3 Tahun 1971, maka terdapat 6 (enam) jenis tindak pidana korupsi, yang diatur dalam pasal 1 sub (1) a sampai e dan sub (2):

1. Tindak Pidana Korupsi Pokok (pasal 1, (1) a dan (1) b dengan unsur-unsur:

- Barang siapa, melawan hukum, memperkaya diri sendiri, orang lain, langsung, tak langsung, merugikan keuangan negara, atau perekonomian negara.

2. Tindak Pidana Korupsi KUHP, dirumuskan dalam sub 1 (c) dengan unsur-unsur :

- Menyalahgunakan kewenangan, kesempatan, karena jabatan atau kedudukan, langsung tak langsung merugikan keuangan negara atau perekonomian negara.

3. Tindak Pidana Korupsi Umum bukan Pegawai Negeri, dirumuskan dalam sub (1) d, dengan iinsur-unsur :

- Barang siapa melakukan kejahatan tercantum dalam pasal-pasal : 209, 210, 387, 388, 415-420, 423, 425 dan 435 KUHP.

4. Tindak Pidana Korupsi karena tidak melapor, dirumuskan dalam sub (1) e, dengan unsur :

- Memberi hadiah, atau janji kepada pegawai negeri

- Ada kekuasaan dan wewenang.
5. Tindak Pidana Korupsi Percobaan, dirumuskan dalam sub (2) dengan unsur-unsur :

- Tanpa alasan wajar, menerima hadiah/janji.

- Tidak melaporkan kepada yang berwajib, perbuatan tidak selesai.

6. Tindak Pidana Korupsi Permufakatan, dirumuskan dalam sub (2) dengan unsur-unsur:

- Ada permufakatan jahat ${ }^{18}$

Kemajuan yang dicanangkan dalam Undang-Undang No : 3 tahun 1971 sebagai pembaharuan atau kebijakan ini berupa :

- Undang-undang ini sekaligus memuat ketentuan hukum pidana materiil dan formil (hukum acaranya).

Dimulainya penerapan sistem pembuktian terbalik terhadap perkara korupsi (pasal 17 dan 18).

Penerobosan akan rahasia bank dimungkinkan atas pasal 9 ayat (1) dan (2) bagi aset-aset terdakwa yang tersimpan di bank.

Ancaman pidana maksimum seumur hidup atau 20 tahun penjara dan atau denda 30 juta ditambah hukum tambahan. Tampak kekhususan/ penyimpangan dan asas penjatuhan pidana yang umum, di sini diterapkannya penjatuhan pidana ganda dalam pidana pokok sesuai pasal 10 KUHP, dalam Tindak Pidana Khusus (Korupsi) dimungkinkan (pasal 28) Undang-Undang No : 3/1971.

Namun upaya pemberantasan Tindak Pidana Korupsi dirasakan tetap tidak berhasil, karena kerugian negara

18 Soedjono Dirdjosisworo, Op Cit. hlm.71. 
perekonomian rakyat kian bertambah parah.

3.7. Periode IV : Lahirnya UndangUndang No : 31 Tahun 1999 tentang Pemberantasan Tindak Pidana Korupsi (LN. RI tahun 1999 No: 140 tanggal 16 Agustus 1999). sebagai tindak laniut ketetapan MPR-RI No : XI/MPR/1998 tentang Pcnyelenggaraan Negara yang Bersih dan Bebas Konipsi. Kolusi dan Nepotisme (KKN), dan Atas Koreksi Undang-Undang No : 3/71 . Adapun pertimbangan untuk dilahirkannya undang-undang ini adalah :

- Bahwa tindak pidana korupsi sangat merugikan keuangan negara atau perekonomian negara, dan menghambat pembangunan nasional, juga menghambat pertumbuhan dan kelangsungan pembangunan nasional yang menuntut efisiensi tinggi

- Bahwa Undang-Undang No : 3 tahun 1971 tentang Pemberantasan Tindak Pidana Korupsi sudah tidak sesuai lagi dengan perkeinbangan kebutuhan hukuin dalam masyarakat, karena itu perlu diganti dengan Undang-Undang Pemberantasan Tindak Pidana Korupsi yang baru sehingga diharapkan lebih efektif dalam mencegah dan memberantas tindak pidana korupsi. ${ }^{19}$ Sedangkan dari perumusan delik clari Tindak Pidana Korupsi Undang-Undang No: 31 Tahun 1999 seita ancaman sanksinya sudah tergolong tegas dan berat. Bagi terdakwanya bisa diancam pidana paling

19 Leden Marpaung, Op Cit., hlm.60. singkat 4 tahun penjara, maksimal 20 tahun atau bahkan hukuman mati (pasal 2 ayat (2) Undang-Undang No : 31/1999 dan denda paling sedikit 200 juta rupiah dan paling banyak 1 (satu) milyar rupiah, dengan tetap menerapkan sistem pembuktian terbalik yang berimbang (jaksa dan terdakwa secara bersama-sama tetap dibebani pembuktian.

Namun dalam perkeinbangan kasuskasus korupsi mulai akhir tahun 1999 memasuki awal tahun 2000, akibat tuntutan arus reformasi yang ingin memberantas korupsi secara tuntas, terhadap UndangUndang No : 31 tahun 1999 yang hanya baru berlaku \pm 1 tahun perlu ditinjau dan diadakan perubahan beberapa pasalnya, maka dikeluarkanlah undang-undang baru sebagai revisi atas undang-undang sebelumnya (Undang-Undang No : 31/1999).

3.8. Periode $\mathrm{V}$ : Laliirnya UndangUndang No : 20 Tahun 2001 tentang Perubahan Atas UndangUndang No : 31 Tahun 1999 tentang Pemberantasan Tindak Pidana Korupsi. mulai berlaku seiak 21 Nopember 2001 (dalam LN RI Tahun 2001 No : 134

Adapun pertimbangan mendasar dikeluarkannya Undang-Undang No : 20 tahun 2001 ini adalah :

1. Bahwa Tindak Pidana Korupsi yang selaina ini terjadi secara meluas, tidak hanya merugikan keuangan negara, tetapi juga merupakan pelanggaran terhadap hak-hak sosial dan ekonomi masyarakat secara luas, sehingga tindak pidana korupsi perlu digolongkan sebagai kejahatan yang pemberantasannya harus dilaknkan 
secara luar biasa.

2. Bahwa untuk lebih menjamin kepastian hukum, menghindari keragaman penafsiran hukum dan memberikan perlindungan terhadap hak-hak sosial dan ekonomi masyarakat, serta perlakuan secara adil dalam memberantas tindak pidana korupsi perlu diadakan perubahan atas Undang-Undang No : 31 Tahun 1999 tentang Pemberantasan Tindak Pidana Korupsi. $^{20}$

Adapun perubahan penting atas Undang-Undang No : 31 Tahun 1999, yang dilakukan oleh Undang-Undang No : 20 Tahun 2001 menyangkut seperti halnya :

Tetap memperlakukan UndangUndang No : 3 Tahun 1971 atas perbuatan-perbuatan korupsi yang dilakukan sebelum Undang-Undang No : 31 Tahun 1999 diberlakukan (hal ini untuk menghindari anggapan bahwa terjadinya kekosongan hukum).

- Karena korupsi terjadi di Indonesia secara sistematik dan meluas, sehingga tidak hanya merugikan keuangan negara, tetapi juga telah melanggar hak-hak sosial dan ekonomi masyarakat secara luas, maka pemberantasan korupsi perlu dilakukan dengan cara luar biasa. Dengan tetap menerapkan kebijakan khusus seperti asas pembuktian terbalik (pasal 37) (terbatas), peradilan inabsentia serta penerapan sanksi pidana mati. Dan yang terbaru dalc.m undang-undang ini dicantumkannya istilahgratifikasi (pemberian dalam arti luas) diatur

20 Leden Marpaung, Op Cit, hlm.62. dalam pasal 12B ayat (1) seperti pemberian komisi uang, barang, tiket perjalanan dan sebagainya dapat digolongkan tindak pidana korupsi.

Ketentuan yang dirubah dalam Undang-Undang No : 31/1999 oleh Undang-Undang No : 20 tahun 2001 yang paling prinsip adalah ketentuan pasal 5 sampai dengan 12 nimusannya dirubah dengan tidak mengacu pasalpasal dalam KUHP tetapi langsung menyebutkan unsur-unsur yang terdapat dalam masing-masing pasal KUHP yang diacu.

Sebagai tindak lanjut Undang-Undang No : 20 tahun 2001 ini ditugaskan pada Komisi Pemberantasan Tindak Pidana Korupsi (KPTPK) yang dibentuk atas dasar undang-undang yang telah disahkan Ketua DPR-R1 Akbar Tanjung tanggal 28 Nopember 2002, dan telah pula disahkan oleh Presiden Megawati tanggal 27 Desember 2002 menjadi UU No : 30 tahun 2002 dengan sebutan UU tentang Komisi Pemberantasan Tindak Pidana Korupsi yang hasilnya kita tunggu dan kinerja KPTPK ini dalam memberantas korupsi di Indonesia.

Menurut pendapat Prof. Barda, bahwa kebijakan pembaharuan terhadap UU Pemberantasan Korupsi selama ini mencakup niang lingkup seperti beirkut:

a. Kebijakan kriminalisasi tunduk pidana korupsi.

b. Kebijakan mengenai subyek tindak pidana koaipsi.

c. Kebijakan sistem pidana dan pemidanaan.

d. Kebijakan mengenai peran serta 
masyarakat.

\subsection{Kekhususan-kekhususan Sebagai Sub Sistem Dalam Wuiud Kebijakan Pidana untuk Penanggulangan dan Pemberantasan Korupsi (Dibidang Hukum Acara)}

\section{a. Asas Pembuktian Terbalik}

Pemberlakuan Asas Pembuktian Terbalik (Omkering Van de bewijslast) di dalam penanganan proses tindak pidana korupsi di Indonesia, hal ini tercantum dalam ketentuan pasal 37 UU No : 20 tahun 2001 tentang perubahan atas UU No : 31 tahun 1999 tentang Pemberantasan Tindak Pidana Korupsi (Pasal 37 Ayat 1, 2, 3, pasal 38b (1, 2, 3, 4, 5, 6) dan pasal 38c).

Di dalam sistem pembuktian terbalik yang diterapkan dalam UU No. 20 tahun 2001 ini menyuratkan makna bahwa terdakwa terlebih dahulu diberikan kesempatan unruk membuktikan dirinya bahwa ia tidak melakukan tindak pidana korupsi (pasal 37 ayat (1)). Dalam hal terdakwa dapat membuktikan bahwa ia tidak melakukan tindak pidana korupsi. maka pembuktian tersebut dipergunakan oleh pengadilan sebagai dasar untuk menyatakan bahwa dakwaan tidak terbukti (pasal 37 ayat (2)). Bahkan lebih jauh dari itu terdakwa hanis menerangkan seluruh harta benda istri/ suami, anak, atau harta benda setiap orang atau korporasi yang diduga mempunyai hubungan dengan perkara yang didakwakan. Tampak disini walaupun diterapkan sistem pembuktian terbalik ini kesulitan yang akan muncul adalah membuktikan kebenaran apa yang dinyatakan terdakwa yang tidak menutup kemungkinan terdakwa secara lihat akan menyembunyikan harta bendanya, yang sulit untuk dilacak oleh jaksa penuntut umum dalam pembuktian yang dilakukannya, karena dengan diterapkannya sistem pembuktian terbalik dalam kasus korupsi akan menghilangkan beban pembuktian bagi jaksa. Sesuai dengan asas oportunitas yang dianut bahwa jaksa penuntut umum sebagai wakil negara mempunyai kewajiban tetap menuntut setiap orang yang diduga berbuat suatu tindak pidana. Berarti dalam pembuktian tindak pidana konipsi disamping diterapkan sistem pembuktian terbalik juga sistem pembuktian menurut KUHAP (sistem pembuktian menurut UU secara negatif) tetap dijalankan (negatif Wettelijke bewijs theone) seperti tertuang dalam pasal 183 KUHAP.

Melihat penerapan versi tersebut berarti sekarang ini dalam pemberantasan tindak pidana korupsi diterapkan sistem pembuktian terbalik yang bersifat terbatas dan berimbang (sesuaipenjelasan UU No. 31 tahun 1999). Kata berimbang menurut pendapat Martiman. Prodjohamidjojo memakai kata "sebanding" (Martiman P, 2001:108).

Diberikannya kesempatan bagi terdakwa untuk menerangkan terlebih dahulu tentang keadaan dirinya bahwa ia tidak melakukan tindak pidana (korupsi), tampak sebagai perwujudan asas presumption of innocence dalam penegakan hukum di bidang korupsi, ini semestinya bila terdakwa tidak dapat membuktikan dirinya tidak melakukan korupsi, secara otomatis tanpa perlu pembuktian dan jaksa penuntut umum, hakim langsung menyatakan terdakwa bersalah (memutus dengan memidana terdakwa), sehingga terwujudlah asas 
penyelenggaraan peradilan cepat, sederhana dan biaya ringan tersebut. Karena korupsi dianggap sangat meresahkan dan dipandang sebagai bahaya laten maka perlulah sudah Indonesia menetapkan bahaya korupsi sebagai keadaan darurat (Prof. Satjipto R, 2001:16) et. Al, Ahmad AIL lebih jauh dinyatakan karena (korupsi) dipandang keadaan darurat maka harus diselesaikan dengan berfikir darurat, bertindak darurat, dan terobosan darurat pula.

Dengan rnehhat peikembaiigan serta tuntutan kebutuhan hukum yang begitu mendesak, sudah semestinya semua kalangan dan profesi hukum di Indonesia untuk meninggalkan pola pikir legalistik formal agar tidak terbelenggu dengan wawasan sempit dalam mencari pola dan penyelesaian kasus-kasus besar yang sifatnya khusus. Paham positivistis klasik dari Jeremy Bentham dan John Austin yang menganggap hukum hanya ada dalam undang-undang saja perlu secara perlahan ditinggalkan, disesuaikan dengan kebutuhan dan tuntutan perkembangan hukum yang kini begitu pesat.

Menurut pendapat dan pandangan pendekar hukum Indonesia yang kini telah tiada Baharuddin Lopadalam penanganan tindak pidana korupsi sudah saatnya diterapkan sistem pembuktian terbalik (Omkenng Van Bewijslast/Reserval of the burden of proof) dalam persidangan pemberantasan korupsi seperti yang berlaku disejumlah negara antara lain di Malaysia, Singapura dan Hongkong.

b. Dalam ketentuan pasal 12-13 UU No : 20 tahun 2001 diatur mengenai perluasan arti pembenan snap bagi pegawai negeri, dengan sebutan "gratifikasi". Dalam penjelasan pasal yang tersebut yang dimaksud dengan gratifikasi (ayat 1) adalah pemberian, pemberian dalam arti luas yakni meliputi pemberian uang, barang, rabat (discount), komisi, pinjaman tanpa bunga, tiket perjalanan, fasilitas penginapan, perjalanan wisata, pengobatan Cuma-Cuma dan fasilitas lainnya. Bentuk kebijakan ini dalam upaya menjaring pelaku-pelaku korupsi agar tidak lolos dari jeratan hukum.

c. Adanya kebijakan penting yang termuat dalam UU No : 20 tahun 2001 atas pembahan UU No : 31 tahun 1999 adalah menyangkut pemberatan, sanksi pidana batk berupa pidana penjara maupun sanksi denda. Ketentuan pasal: $5,6,7,8,9,10,11$ dan 12 rumusannya diubah dengan tidak mengacu pasalpasal dalam KUHP, tetapi langsung menyebutkan unsur-unsur yang terdapat dalam masing-masing pasal KUHP yang diacu sehingga pidana penjara minimal 1 tahun, maksimal pidana penjara seumur hidup atau 20 tahun, dengan minimal denda 50 juta dan maksimal I milyard (pasal 2 ayat (2) dengan pidana mati.

d. Adanya hak dari negara untuk melakukan gugatan perdata, bila diduga terpidana setelah dijatuhi putusan berkekuatan hukum tetap, masih ada kekayaan/harta benda yang diduga diperoleh secara tidak sah, maka terpidana atau alili warisnya bisa digugat secara perdata (pasal 38c UU No : 20 tahun 2001).

e. Terbentuknya UU No : 30 tahun 
2002 tentang Komisi Pemberantasan

Tindak Pidana Korupsi adalah langkah kebijakan paling akhir pemerintah bersama lembaga legislatif di bidang pemberantasan korupsi bagi Indonesia, selaku lembaga khusus dengan mengemban tugas, wewenang dan kewajiban yang amat luas di bidang hukum acara seperti melakukan penyelidikan, penyidikan dan penuntutan terhadap tindak pidana korupsi (pasal : 6 huruf c), dan melakukan tindakan-tindakan pencegalian tindak pidana korupsi (pasal 6 huruf d UU No : 30 tahun 2002).

Demikian beberapa langkah kebijakan dalam pemberantasan korupsi sebagai terobosan dibidang hukum acara pidana, yang menyimpang dari ketentuan-ketentuan umum hukum acara pidana berdasarkan KUHAP/UU No. 8 tahun 1981.

\section{PENUTUP}

\subsection{Simpulan}

1. Adapun sebagai langkah kebijakan pemerintah bersama badan legislatif yang diambil/ditempuh dalam peraturan perundang-undangan dan pemberantasan korupsi di Indonesia selama ini berupa :

a. Sudah sejak awal kemerdekaan Indonesia mulai dekade tahun 50 an merintis kearan kebijakan aturan korupsi (dipelopori oleh kalangan militer berupa menciptakan beberapa peraturan, dilanjutkan beberapa kali penyempurnaan peraturan (berupa peraturan pemerintah)

b. Dalam undang-undang korupsi yang sedang diberlakukan (UU No. 1 tahun 1999 jo UU No. 20 tahun 2001) telah diupayakan terobosan-terobosan khusus seperti pengaturan pidana yang tinggi di bidang hukum acaranya diciptakan dan diberlakukannya berbagai penyimpangan dari ketentuan umum, dicanangkannya kriminalisasi, kebijakan dibidang pidana dan pemidanaan terhadap pelaku kompsi dengan pidana yang tinggi bahkan pidana mati, perluasan subyek hukum, melibatkannya peran serta masyarakat secara luas, terakhir diciptakannya institusi baru dan khusus yang independen seperti Komisi Pemberantasan Korupsi

c. Untuk perspektif kedepan dalam penanganan korupsi ini masih menunggu kinerja lembaga komisi pemberantasan tindak pidana korupsi ini, yang memegang dan mengemban mandat undang-undang No : 30 tahun 2002.

2. Untuk mencapai hasil yang diharapkan dalam penanganan korupsi tidak hanya cukup dengan mengadakan perubahan atau penggantian undang-undang korupsi saja (law reform), namun harus diupayakan lain dilaksanakan pendekatan strategi integral atau memperbaiki keseluruhan kausa dan kondisi yang menjadi faktor kriminogen untuk terjadinya kejahatan korupsi

\subsection{Saran}

1. Untuk tercapainya hasil pemberantasan korupsi yang baik maka kinerja subsub sistem yangmendukung sistem tersebut (struktur, substansi dan budaya 
hukum) harus berperan secara simultan dan terpadu, sesuai harapan bekerjanya teori sistem yang efektif dari Lawrence Meir Friedman sehingga kesulitan penanganan pemberantasan korupsi harapan besar bisa tertanggulang

2. Agar dalam pemberantasan korupsi peran serta masyarakat seperti Lembaga Swadaya Masyarakat (LSM) dan kalangan perguruan tinggi ikut andil memberi sumbangan pemikiran ke arah pemberian masukan pemikiran strategis ke depan guna memberantas korupsi secara optimal.

\section{DAFTAR PUSTAKA}

All Achmad, 2001, Keterpurukan Hukum di Indonesia (Penyebab dan Solusmya) Ghalia Indonesia, Jakarta. Barda Nawawi Arief, 2001, Masalah Penegakan Hukum dan Kebijakan Penanggulangan Kejahatan, Cetakan 1, Penerbit PT. Citra Aditya Bakti, Bandung.

Departemen Pendidikan dan Kebudayaan Republik Indonesia, 1976, Kamus Besar Bahasa Indonesia. Terbitan Balai Pustaka, Jakarta.

Hamzah, Andi, 1986, Sistem Pidana dan Pemidanaan Indonesia, Pradnya Paramita, Jakarta.

Harkristuti Harkrisnowo, 2002, Sistem Peradilan Pidana Terpadu (Dalam Majalah Komisi Hukum Nasional (KHN Rl), Jakarta.

Hakim Garuda Nusantara, Abdul, 2002, Pengadilan Khusus Korupsi (Solusi Alternatif Penyelesaian Kasus Korupsi), dalam Tajuk Majalah Komisi Hukum Nasional-KHN, Jakarta.
Irfan Islamy, 1984, Kebijakan Publik, Cetakan I, Karunika, Jakarta.

K. Wantjik Saleh, 1983, Tmdak Pidana Korupsi dan Snap. Get. ke 5, Ghalia Indoaesia Jakarta

Lammtang, P.A.F, 1984, Hukum Penitensier Indonesia, Armico, Bandung.

Leden Marpaung, 2001, Tmdak Pidana Korupsi Pemberantasan dan Pencegahan, Penerbit Jambatan, Jakarta.

Lopa Baharuddin, 1996, Masalah-masalah Politik, Hukum, Sosial, Budaya, Agama (sebuah pemikiran), Cetakan 1, Pustaka Harapan, Jakarta.

Moeljatno, 1978, KUHP (Terjemahan), Tanpa Penerbit.

Muhari Agus Santoso, 2002, Paradigma Baru Hukum Pidana. Averroes Press, Cet. 1 Malang.

Muladi, 1992, Lembaga Pidana Bersyarat, Alumni, Bandung.

Muladi dan Barda Nawawi Arief, 1992, Teon-Teori dan Kebijakan Pidana, Alumni Bandung.

Packer, H.L, 1968, The Limits of The Criminal Sunction, First Publisher, Stanford University, California.

Purwati, 2003, Hasil Perkuliahan Peinbaharuan Hukum Pidana Semester II 2003/2004. Program Magister (S2) Ilmu Hukum, Konsentrasi Hukum dan Sistem ^Peradilan Pidana, Universitas Udayana Denpasar 15 April 2003.

Sudarto,1975, Hukum dan Hukum Pidana. Sinar Baru Bandung.

Sudarto, 1983, Hukum Pidana dan Perkembangan (Kajian Terhadap PembahamanHukum Pidana), Penerbit 
Sinar Baru, Bandung.

Sahetapy, 2002, Etik Profesi, (Dalam

Majalah Komisi Hukum NasionalKHN, Jakarta.

Soedjono Dirdjosisworo, 1984, Fungsi

Perundang-Undangan Pidana Dalam

Penanggulangan Koaipsi di Indonesia,

Penerbit Sinar Baru, Bandung.

Syeh Hussein Alatas, 1983, Sosiologi

Korupsi (sebuah Penjelajahan dengan

Data Kotemporer), LP3ES, Jakarta.

Widnyana I Made, 1988, Pidana dan

Permasalahannya, Dikeluarkan oleh

Jurusan HukumPidanaFakultas Hukum

Universitas Udayana, Denpasar. 